\title{
Yield, Nitrogen Uptake and Nitrogen Leaching of Sensor-Based Fertigation-Cultured Tomato in a Shallow Groundwater Region: Effect of Shallow Groundwater on Tomato Irrigation
}

\author{
Jinji Zhang ${ }^{1}$, Zhuangzhuang $\mathrm{Cao}^{1}$, Haibo Dai ${ }^{1}$, Zhiping Zhang ${ }^{1} \&$ Minmin Miao ${ }^{1}$ \\ ${ }^{1}$ School of Horticulture and Plant Protection, Yangzhou University, Yangzhou, China \\ Correspondence: Minmin Miao, School of Horticulture and Plant Protection, Yangzhou University, Yangzhou, \\ Jiangsu 225009, P.R. China. Tel: 86-139-5275-1392. E-mail: mmmiao@yzu.edu.cn
}

Received: September 8, 2019

Accepted: October 31, $2019 \quad$ Online Published: December 15, 2019

doi:10.5539/jas.v12n1p10

URL: https://doi.org/10.5539/jas.v12n1p10

\begin{abstract}
Fertigation with surface drip has been introduced and broadly applied for vegetable cultivation in the Eastern China, which presents high precipitation and always has shallow groundwater. To estimate the influence of high groundwater level on the tomato nitrogen $(\mathrm{N})$ and water use efficiency and develop new sensor-based fertigation technology, experiments were executed in plastic greenhouse in the experimental farm of Yangzhou University located in the suburban of Yangzhou city during 2016-2017 growing seasons using a block randomization with three replications. Three $\mathrm{N}$ dosages and 4 watering treatments were carried out in this experiment. The data indicated that irrigation threshold of $-35 \mathrm{kPa}$ was optimum to get the maximum production of tomato. In this treatment, the value of estimated plant evapotranspiration (ETc) was much higher than total applied water volume, suggesting high groundwater table had a significant contribution on the tomato ETc and a sensor-based irrigation strategy should be more accurate than the simulated ETc irrigation method to calculate the water demand under this condition. In addition, our results indicated that high groundwater level had a positive effect to alleviating $\mathrm{N}$ leaching. Finally, we can conclude that fertigation technology enhanced the $\mathrm{N}$ use efficiency (NUE) and water use efficiency (WUE) and three fourths of the calculated $\mathrm{N}$ dosage (according to a traditional nutrient equation) was sufficient to optimize tomato yield.
\end{abstract}

Keywords: high groundwater table, irrigation threshold, nitrogen use efficiency, tomato, water use efficiency

\section{Introduction}

The middle and lower reaches of Changjiang River in China range from $111^{\circ}$ to $123^{\circ}$ east longitude and $27^{\circ}$ to $34^{\circ}$ north latitude, covering an area of about $200,000 \mathrm{~km}^{2}$. In this region, the elevation is $5 \mathrm{~m}$ to $100 \mathrm{~m}$ (mostly below $50 \mathrm{~m}$ ), the annual precipitation is 1000 to $1400 \mathrm{~mm}$ and the mean annual temperature is 14 to $18{ }^{\circ} \mathrm{C}$ (http://www.cma.gov.cn/). As a result, the water table of this region always remains at a high level. Due to its warm and humid climate, the middle and lower reaches of Changiiang River is one of the most important regions for vegetable production in China. Un-heated plastic greehouse is the most popular facility for vegetable production in this region. Annual thermophilous vegetables, such as solanaceous crops, beans and cucurbits, are always delayed-cultured in the autumn or accelerating-cultured in the spring in these walk-in plastic greenhouses. According to the official data, in 2013 there were about 1.7 million hectares of un-heated plastic greenhouse in China, among which about 0.44 million hectares were located in the middle and lower reaches of Changjiang River (Ministry of Agriculture of China, 2014).

Tomato is one of the most popular vegetables grown in these walk-in greenhouses in the middle and lower reaches of Changiiang River because of their delicious taste and high nutritional value. Tomato is a long season crop with high water and nitrogen $(\mathrm{N})$ requirements and tomato yield is sensitive to the deficiency of soil water and N (He, Q. Chen, Jiang, X. P. Chen, \& Zhang, 2007; Wang \& Xing, 2017). On the other hand, growers always apply excessively irrigation water and high $\mathrm{N}$ rates to minimize risk of yield reductions due to water and $\mathrm{N}$ limitations, which usually cause serious water and $\mathrm{N}$ loss. Therefore, the irrigation and fertilization strategy should be carefully managed to minimize the water and $\mathrm{N}$ leaching without yield reduction. The response of tomato nitrogen use efficiency (NUE), water use efficiency (WUE) and yield to different irrigation and fertilization programs has been studied detailedly in different regions of the world in the past decades (Du, H. X. 
Cao, Liu, Gu, \& Y. X. Cao, 2017; Hou et al., 2017; X. L. Li, Liu, G. T. Li, Lin, \& Jensen, 2010; Wang \& Xing, 2016; Zotarelli, Scholberg, Dukes, Muñozcarpena, \& Icerman, 2009). The optimal schedule varied among different reports, depending on the cultivation methods, the soil properties and the climate conditions.

Recently, owing to the growing labor cost and the rising attention of the agricultural source pollution, fertigation with surface drip and plastic mulch culture has been commonly used in this region. In addition, the sensor-based automatic irrigation system has gradually been applied to realize the precision irrigation and further reduce the labor cost. However, little study about fertilization and irrigation management has been conducted for these new vegetable production systems. On the other hand, researches about the nitrogen and water management of tomato were always conducted in the semi-arid or arid areas (Du et al., 2017; He et al., 2007). Unlike these semi-arid or arid regions, the middle and lower reaches of Changjiang River has plenty of rainfall and high groundwater level. According to our measurements, the depth of groundwater table is easily to be found less than $1 \mathrm{~m}$ in vegetable greenhouses at different sites in this area. It was reported that the shallow groundwater always has a considerable contribution to the total crop water requirement (Han, Zhao, Šimùnek, \& Feng, 2015; Liu, Pereira, \& Fernando, 2006; Ramos, Simionesei, Jauch, Almeida, \& Neves, 2017; Wu, Liu, Paredes, Duan, \& Pereira, 2015). Therefore, the management of fertilization and irrigation of vegetable crops should be different widely between arid and humid regions. However, up to date little research has focused on the water and $\mathrm{N}$ application strategies in shallow water table regions.

The purpose of this study is to investigate the response of tomato yield, dry matter, $\mathrm{N}$ uptake and $\mathrm{N}$ leaching to different fertilization and irrigation programs and collect data to improve the sensor-based fertigation technology for plastic walk-in greenhouse tomato cultivation in the middle and lower reaches of Changjiang River.

\section{Materials and Methods}

\subsection{Experimental Site and Soil Properties}

During spring-summer seasons in 2016 and 2017, the experiment was carried out at a vegetable farm $\left(32^{\circ} 68^{\prime} 82^{\prime \prime} \mathrm{N}, 119^{\circ} 59^{\prime} 10^{\prime \prime} \mathrm{E}\right)$ in Yangzhou, Jiangsu Province, a typical region of the middle and lower reaches of Changjiang River. The year-round average temperature at the experimental site is $16.2{ }^{\circ} \mathrm{C}$. The average annual rainfall is approximately $1021 \mathrm{~mm}$, of which about 225 rainfall occurs in the spring (from March 1 to May 30) and $480 \mathrm{~mm}$ in the summer (from June 1 to August 31). Average annual evaporation is $937.7 \mathrm{~mm}$ (from the free water surface). Silt loam represents the main soil texture at the experiment region. The chemical and physical characteristics of the soil was shown in Table 1.

Table 1. Physical and chemical characteristics of the 0-30 $\mathrm{cm}$ depth of the experimental soil

\begin{tabular}{|c|c|c|}
\hline Properties & 2016 & 2017 \\
\hline Clay $(\%)$ & 22 & 23 \\
\hline Loam $(\%)$ & 56 & 57 \\
\hline Sand $(\%)$ & 22 & 20 \\
\hline Bulk density $\left(\mathrm{g} \mathrm{cm}^{-1}\right)$ & 1.41 & 1.40 \\
\hline Field capacity $(\%)$ & 26.9 & 25.7 \\
\hline Field capacity $(\mathrm{mm})$ & 113.9 & 107.9 \\
\hline Wilting Point (\%) & 14.7 & 14.2 \\
\hline Wilting Point (mm) & 62.8 & 60.2 \\
\hline $\mathrm{pH}$ & 6.4 & 6.4 \\
\hline Organic matter content $(\%)$ & 1.97 & 2.00 \\
\hline Salinity $\left(\mathrm{dS} \mathrm{m}^{-1}\right)$ & 0.39 & 0.40 \\
\hline Total nitrogen $\left(\mathrm{g} \mathrm{kg}^{-1}\right)$ & 1.05 & 1.05 \\
\hline Available nitrogen $\left(\mathrm{mg} \mathrm{kg}^{-1}\right)$ & 108.4 & 112.3 \\
\hline Available phosphorous $\left(\mathrm{P}_{2} \mathrm{O}_{5} \mathrm{mg} \mathrm{kg}^{-1}\right)$ & 20.7 & 22.9 \\
\hline Available potassium $\left(\mathrm{K}_{2} \mathrm{O} \mathrm{mg} \mathrm{kg}{ }^{-1}\right)$ & 136.2 & 147.3 \\
\hline
\end{tabular}

\subsection{Crop Management and Treatments}

The experiments were executed in the typical un-heated plastic greenhouses. These walk-in tunnels for experiment were $50 \mathrm{~m}$ long, $8 \mathrm{~m}$ wide, $2.3 \mathrm{~m}$ high and oriented south-north, which are typical in the middle and 
lower reaches of Changjiang River. The tunnel frame was covered with polyethylene film $(0.06 \mathrm{~mm})$ during the whole period the experiment. In 2016 and 2017, Tomato seedlings at 7-leaf stage were transplanted in these greenhouses at March 1. Dairy manure $45 \mathrm{~m}^{3} \mathrm{ha}^{-1}$ (containing $32.84 \mathrm{~kg} \mathrm{~N}, 64.92 \mathrm{~kg} \mathrm{P}_{2} \mathrm{O}_{5}$ and $80.42 \mathrm{~kg} \mathrm{~K}_{2} \mathrm{O}$ ) was mixed in the soil $(20 \mathrm{~cm})$ during bedding. The transparent plastic mulch and the drip irrigation system were equipped before transplanting. The vent was closed during raining and the ventilation was executed everyday according to the humid and temperature inside the greenhouse. Disease and pest control was carried out if necessary. All side shoots of tomato plants were mechanically removed. Fruits were harvested everyday when they met the market standard. The last harvest date was at July 3 in 2016 and July 7 in 2017. The distance between plants and rows was demonstrated in the Figure 1.

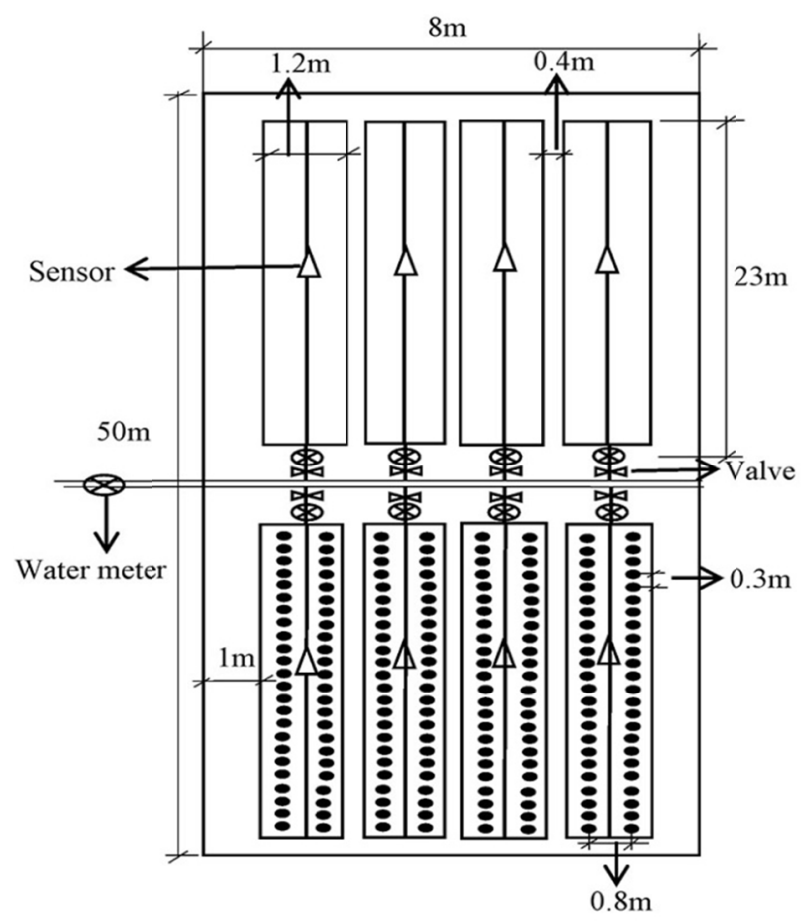

Figure 1. Schematic layout of the plots, fertigation arrangement, sensor irrigation system and the distance of plants and rows in greenhouses

Three $\mathrm{N}$ rates and 4 irrigation water schedules (totally 12 treatments) were arranged in this experiment (Tables 2 and 3). The $\mathrm{N}_{\mathrm{R}}$ (chemical $\mathrm{N}$ recommended) was calculated according to the soil nutrient balance, in which the expected tomato yield was 100 tons $\mathrm{ha}^{-1}$, the soil available NUE is $45 \%$, the organic fertilizer NUE is $20 \%$, and the chemical fertilizer NUE is $50 \%$, according to local experiences. Therefore, $3 \mathrm{~N}$ rates were calculated as $\mathrm{N} 1=$ $0.5 \mathrm{~N}_{\mathrm{R}}, \mathrm{N} 2=0.75 \mathrm{~N}_{\mathrm{R}}$ and $\mathrm{N} 3=\mathrm{N}_{\mathrm{R}}$. The exact dosage of chemical fertilizers was list in Table 2. Potassium sulfate, calcium superphosphate and urea were used as chemical fertilizers to provide potassium, phosphorus and $\mathrm{N}$, respectively. Urea and potassium sulfate were dissolved and applied by the fertigation system during plant growth. To meet the plant need, twenty percent urea was used from 0 to 40 days after transplanting, forty percent urea and forty percent potassium sulfate were used from the 40 to 80 days after transplanting, and forty percent urea and sixty percent potassium sulfate were used from 80 days after planting to the end, according to $\mathrm{N}$ and potassium assimilating patterns of tomato plants (data from previous local experiments, unpublished). In each irrigation event, the dosage of urea and potassium sulfate solution were used averagely according to the total amount and irrigation time in each growth stage. The calcium superphosphate was mixed in the soil when bedding as a base fertilizer. 
Table 2. Applications of chemical fertilizer in the experiments

\begin{tabular}{llll}
\hline Year & $\mathrm{N}\left(\mathrm{kg} \mathrm{ha}^{-1}\right)$ & $\mathrm{P}_{2} \mathrm{O}_{5}\left(\mathrm{~kg} \mathrm{ha}^{-1}\right)$ & $\mathrm{K}_{2} \mathrm{O}\left(\mathrm{kg} \mathrm{ha}^{-1}\right)$ \\
\hline \multirow{2}{*}{2016} & 187.86 & & \\
& 281.81 & 176.77 & 467.88 \\
& 375.72 & & \\
& 180.61 & & \\
2017 & 270.92 & 149.47 & \\
& 361.22 & & \\
\hline
\end{tabular}

Table 3. Applications of irrigation in the experiments

\begin{tabular}{llll}
\hline Year & Treatment & Irrigation times* & Irrigation water dosage $(\mathrm{mm})^{*}$ \\
\hline \multirow{2}{*}{2016} & -50 to $-35 \mathrm{kPa}$ & 22 & 207 \\
& -35 to $-20 \mathrm{kPa}$ & 28 & 258 \\
& -20 to $-5 \mathrm{kPa}$ & 34 & 319 \\
& -50 to $-5 \mathrm{kPa}$ & 10 & 268 \\
2017 & -50 to $-35 \mathrm{kPa}$ & 23 & 246 \\
& -35 to $-20 \mathrm{kPa}$ & 29 & 310 \\
& -20 to $-5 \mathrm{kPa}$ & 35 & 375 \\
& -50 to $-5 \mathrm{kPa}$ & 11 & 321
\end{tabular}

Note. * Irrigation times and irrigation water dosages include the $45 \mathrm{~mm}$ water applied at the first day and the same amount water at the second day after transplanting, respectively.

A sensor based irrigation system was applied in this experiment. Four irrigation schedules were set up as: -50 to $-35 \mathrm{kPa},-35$ to $-20 \mathrm{kPa},-20$ to $-5 \mathrm{kPa}$, and -50 to $-5 \mathrm{kPa}$. Prior to the beginning of the irrigation treatments, plants were applied with $45 \mathrm{~mm}$ water at the first day and the same water amount at the second day after transplanting for a better plant establishment. The exact values of irrigation time and dosage of the treatments were list in Table 3. The last irrigation was at June 25 in 2016 and June 29 in 2017, respectively.

In this experiment, each greenhouse contained 4 plots, as shown in Figure 1. Thus, each replicate included 3 tunnels. The experiment included 3 replicates and totally need 9 tunnels per year. To block the cross movement of $\mathrm{N}$ and water, in the same tunnel, plots were segregated with PVC plates (depth of $0.5 \mathrm{~m}$ ). The fertigation system was controlled independently to allow us conducting the randomized block factorial experimental design.

\subsection{Measurements}

Soil samples $(0$ to $30 \mathrm{~cm})$ were taken for parameter analysis listed in Table 1, according to Lu (1999). The groundwater level was monitored by water table sensors (YKKT-1E, Xian Xingyi Yibiao Technology CO., LTD, China), one sensor per greenhouse. A weather station (NHQXZ601, Wuhan Zhongke Nenghui Technology Development CO., LTD, China) was equipped in one of the experiment greenhouses to collect weather data for $\mathrm{ET}_{0}$ estimation. The rainfall data was collected by another weather station set up outside the greenhouses. Flow meters were used to control the irrigation water dosage of each treatment (one flow meter per plot).

Total fruit weights harvested from each plot were record (transformed into $\mathrm{kg} \mathrm{ha}^{-1}$ ). After the last harvest, 5 plants in each replicated plot were selected randomly to measure the dry weight of roots, fruits, stems and leaves (including the harvested fruits and pruned side shoots). The dry matter of different organs was assayed by drying samples at $65^{\circ} \mathrm{C}$ to a constant weight and total dry weight was evaluated as the sum dry matter of all organs. The $\mathrm{N}$ contains of roots, fruits, stems and leave were measured by the micro Kjeldahl protocol of digestion and titration individually (Bremner \& Mulvane, 1982). The total $\mathrm{N}$ uptake was estimated using the dry matter and the $\mathrm{N}$ concentration of each tissue. Before planting, 3 self-made lysimeters were inbuilt in each plot with their collection surface at $30 \mathrm{~cm}$ depth to collect $\mathrm{N}$ leaching. The soil solution collected in each lysimeter was aspirated using a syringe with a long hose (Figure 2). Water samples were sampled every 5 days from lysimeters. The receiver of the lysimeter is large enough to avoid the overbrimming. Total $\mathrm{N}$ quantities of the leachates in lysimeters were assayed using a continuous flow analyzer (Futura, Alliance, France). Nitrogen leaching $\left(\mathrm{kg} \mathrm{ha}^{-1}\right)$ 
of each treatment was estimated as the ratio of one hectare to the collecting surface area of 3 lysimeters times the total $\mathrm{N}$ leaching in the lysimeters. In this experiment, water use efficiency (WUE) was evaluated as fruit yield divided by total irrigated water $\left(\mathrm{kg} \mathrm{mm}^{-1}\right)$, and the $\mathrm{N}$ use efficiency (NUE) was defined as fruit yield divided by total chemical $\mathrm{N}$ application $\left(\mathrm{kg} \mathrm{kg}^{-1}\right)$.

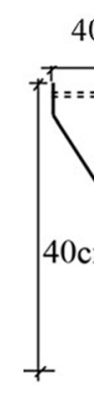

\section{$40 \mathrm{~cm}$}

$=s=s=s=s$

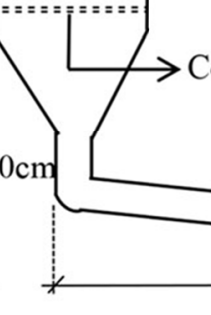
Collection surface

Figure 2. Diagrammatic drawing of the self-made lysimeter used in the experiment

\subsection{Statistical Analysis}

Two-way ANOVAs were performed to determine significances among experimental years, irrigation programs and $\mathrm{N}$ dosages with SPSS Statistics 18. The significance of treatment effects and their interactions was estimated using the F-test, and the least significant difference (LSD) were used to comparing means at the 0.05 level.

\section{Results}

\subsection{Precipitation and Underground Water Level}

Daily rainfall and the groundwater table level in the experimental greenhouse were observed. As shown in Figure 3, the precipitation during the experiment stage was $592.1 \mathrm{~mm}$ in 2016 and $274.9 \mathrm{~mm}$ in 2017. In both years, about half of rainfall occurred in June (forty-nine percent in 2016 and forty-six percent in 2017 during the cropping period). The depth of water table ranged from 11 to $78 \mathrm{~cm}$ in 2016 and 12 to $83 \mathrm{~cm}$ in 2017. In an addition, a closely relationship between the rainfall and the depth of groundwater table was observed, although the ventilation opening of greenhouses was closed when raining. 


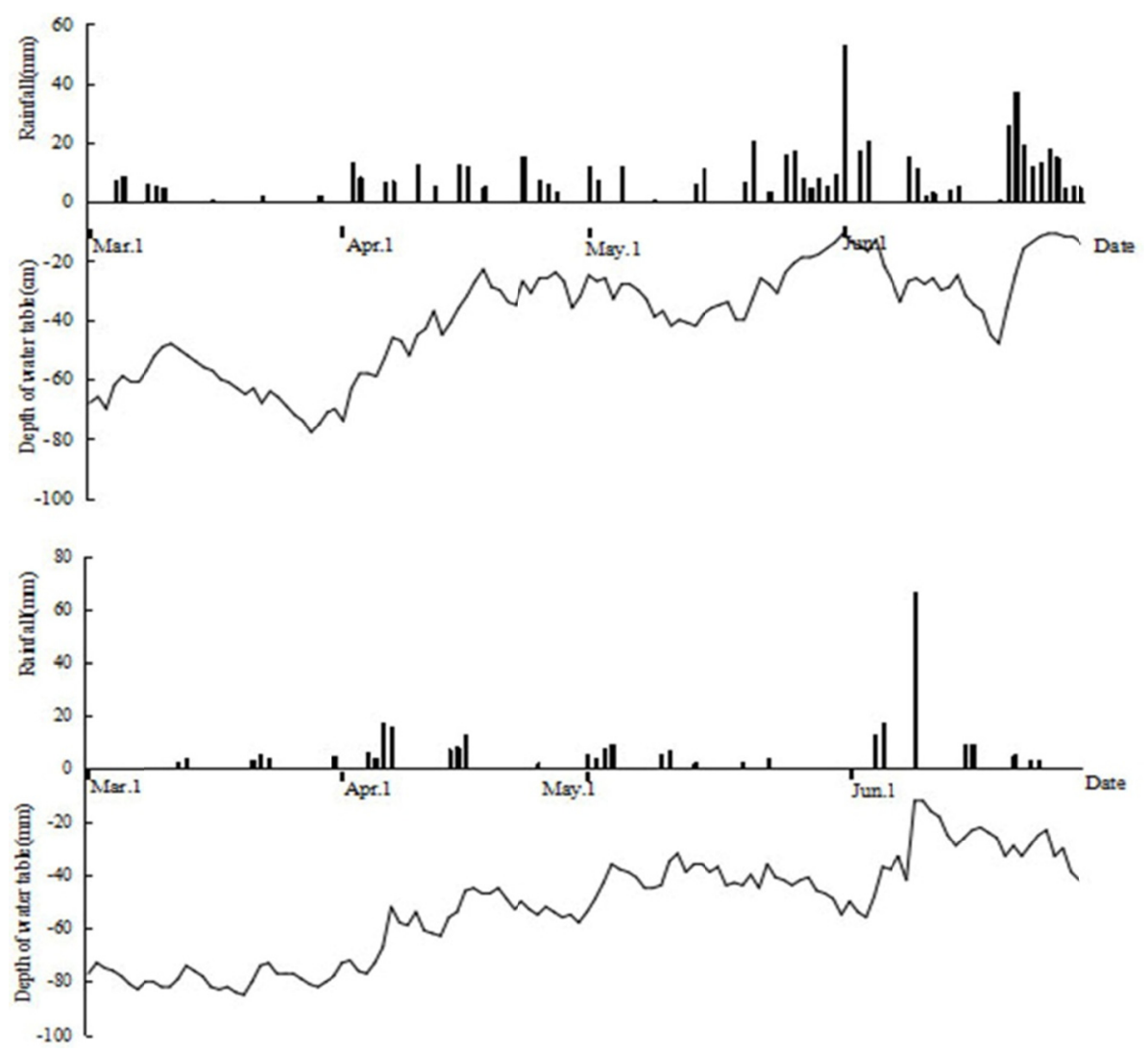

Figure 3. Daily data of rainfall and depth of groundwater table in 2016 and 2017 during plant growth

\subsection{Tomato Yield}

As shown in Table 4, tomato yield ranged from $64.3(\mathrm{~N} 1-50 \mathrm{kPa}$ to $-35 \mathrm{kPa}, 2017)$ to 126.5 tons $^{-1} \mathrm{p}^{-}$(N2 -35 to $-20 \mathrm{kPa}, 2017$ ) over 2 study years. Basically, the response of tomato yields to different $\mathrm{N}$ rates could be summarized as N3 $>\mathrm{N} 2>\mathrm{N} 1$ each year. However, a significant irrigation $\times \mathrm{N}$ interaction on tomato yield was observed. In -50 to $-35 \mathrm{kPa}$ and -35 to $-20 \mathrm{kPa}$ treatments, there was no remarkable difference between $\mathrm{N} 2$ and $\mathrm{N} 3$, while in -20 to $-5 \mathrm{kPa}$ and -50 to $-5 \mathrm{kPa}$, tomato yield of $\mathrm{N} 3$ was remarkably higher than that of $\mathrm{N} 2$. The response of tomato yield to different irrigation treatments also revealed an irrigation $\times \mathrm{N}$ interaction effect. In N1, the tomato yield of different irrigation treatments was -35 to $-20 \mathrm{kPa}>-50$ to $-5 \mathrm{kPa}>-20$ to $-5 \mathrm{kPa}>-50$ to -35 $\mathrm{kPa}$. While in $\mathrm{N} 2$ and $\mathrm{N} 3$, it was -35 to $-20 \mathrm{kPa}>-20$ to $-5 \mathrm{kPa}>-50$ to $-5 \mathrm{kPa}>-50$ to $-35 \mathrm{kPa}$. In addition, statistical analysis of the experimental results suggested there were significant differences in the yields between two experimental years $(2016<2017)$. Statistically, the $(\mathrm{N} 2,-35$ to $-20 \mathrm{kPa})$ combination was the optimal treatment to achieve the highest tomato yield in the experimental condition.

Table 4. Tomato yield under different $\mathrm{N} \times$ irrigation combinations in 2016 and 2017 (tons ha $\left.{ }^{-1}\right)$

\begin{tabular}{|c|c|c|c|c|c|c|c|c|}
\hline \multirow{2}{*}{ Treatment } & \multicolumn{4}{|c|}{2016} & \multicolumn{4}{|c|}{$2017^{\mathrm{NS}}$} \\
\hline & N1 & N2 & N3 & Average & N1 & N2 & N3 & Average \\
\hline-50 to $-35 \mathrm{kPa}$ & $67.3 \mathrm{~g}$ & $87.8 \mathrm{e}$ & $90.1 \mathrm{de}$ & $81.7 \mathrm{C}$ & $64.3 \mathrm{~h}$ & $89.3 \mathrm{f}$ & $92.6 \mathrm{ef}$ & $80.1 \mathrm{C}$ \\
\hline-35 to $-20 \mathrm{kPa}$ & $94.6 \mathrm{~cd}$ & $121.9 \mathrm{a}$ & $120.0 \mathrm{a}$ & $112.2 \mathrm{~A}$ & $97.8 \mathrm{~d}$ & $126.5 \mathrm{a}$ & $121.5 \mathrm{~b}$ & $115.3 \mathrm{~A}$ \\
\hline-20 to $-5 \mathrm{kPa}$ & $78.7 \mathrm{f}$ & $109.4 \mathrm{~b}$ & $123.6 \mathrm{a}$ & $103.9 \mathrm{AB}$ & $80.2 \mathrm{~g}$ & $111.4 \mathrm{c}$ & $119.3 \mathrm{~b}$ & $103.6 \mathrm{AB}$ \\
\hline-50 to $-5 \mathrm{kPa}$ & $86.2 \mathrm{e}$ & $98.5 \mathrm{c}$ & $110.8 \mathrm{~b}$ & $98.5 \mathrm{~B}$ & $88.7 \mathrm{f}$ & $96.3 \mathrm{~d} \mathrm{e}$ & $111.2 \mathrm{c}$ & $98.7 \mathrm{~B}$ \\
\hline Average & $81.7 \mathrm{~B}$ & $104.4 \mathrm{~A}$ & $111.1 \mathrm{~A}$ & 99.1 & $82.8 \mathrm{~B}$ & $105.9 \mathrm{~A}$ & $111.2 \mathrm{~A}$ & 99.4 \\
\hline
\end{tabular}

Note. Values with different lower case letters in the $\mathrm{N} \times$ irrigation combinations (totally 12 treatments each year) are significantly different at the 0.05 level. Values with different upper case letters in the same average column or the same average row each year are also significantly different at the 0.05 level. The same definitions apply to Tables 5-9. Ns indicate no significant difference between 2016 and 2017 at the 0.05 level. The same definitions apply to Tables 5-7. 


\subsection{Dry Matter}

Similar to the response of fresh yield, the tomato dry matter of N2 and N3 was markedly higher than that of N1, while there was no remarkable difference of plant dry matter between $\mathrm{N} 2$ and $\mathrm{N} 3$. The similar irrigation $\times \mathrm{N}$ interaction on tomato dry matter was also observed, i.e., In N1, the plant dry matter of different irrigation treatments was -35 to $-20 \mathrm{kPa}>-50$ to $-5 \mathrm{kPa}>-20$ to $-5 \mathrm{kPa}>-50$ to $-35 \mathrm{kPa}$. While in N2 and N3, it was -35 to $-20 \mathrm{kPa}>-20$ to $-5 \mathrm{kPa}>-50$ to $-5 \mathrm{kPa}>-50$ to $-35 \mathrm{kPa}$. There was no significant difference of plant dry matter data between 2016 and 2017.

Table 5. Tomato total dry matter under different $\mathrm{N} \times$ irrigation combinations in 2016 and 2017 (tons ha ${ }^{-1}$ )

\begin{tabular}{|c|c|c|c|c|c|c|c|c|}
\hline \multirow{2}{*}{ Treatment } & \multicolumn{4}{|c|}{2016} & \multicolumn{4}{|c|}{$2017^{\mathrm{NS}}$} \\
\hline & N1 & N2 & N3 & Average & N1 & N2 & N3 & Average \\
\hline-50 to $-35 \mathrm{kPa}$ & $7.0 \mathrm{i}$ & $10.9 \mathrm{fg}$ & $10.4 \mathrm{~g}$ & $9.4 \mathrm{~B}$ & $6.4 \mathrm{f}$ & $10.9 \mathrm{~cd}$ & $11.7 \mathrm{c}$ & $9.67 \mathrm{C}$ \\
\hline-35 to $-20 \mathrm{kPa}$ & 11.9 ef & $16.1 \mathrm{ab}$ & $15.1 \mathrm{bc}$ & $14.4 \mathrm{~A}$ & $12.0 \mathrm{c}$ & $16.2 \mathrm{a}$ & $15.5 \mathrm{ab}$ & $14.6 \mathrm{~A}$ \\
\hline-20 to $-5 \mathrm{kPa}$ & $9.3 \mathrm{~h}$ & $13.8 \mathrm{~d}$ & $16.6 \mathrm{a}$ & $13.2 \mathrm{~A}$ & $9.5 \mathrm{e}$ & $14.8 \mathrm{~b}$ & $15.9 \mathrm{a}$ & $13.4 \mathrm{AB}$ \\
\hline-50 to $-5 \mathrm{kPa}$ & $10.1 \mathrm{gh}$ & $12.5 \mathrm{e}$ & $14.0 \mathrm{~cd}$ & $12.2 \mathrm{~A}$ & $10.3 \mathrm{de}$ & $11.6 \mathrm{c}$ & $14.8 \mathrm{~b}$ & $12.2 \mathrm{~B}$ \\
\hline Average & $9.6 \mathrm{~B}$ & $13.3 \mathrm{~A}$ & $14.0 \mathrm{~A}$ & 12.3 & $9.6 \mathrm{~B}$ & $13.4 \mathrm{~A}$ & $14.5 \mathrm{~A}$ & 12.5 \\
\hline
\end{tabular}

\subsection{N Uptake}

In all 4 irrigation treatments, the plant $\mathrm{N}$ uptake increased with the increase of $\mathrm{N}$ dosage from $\mathrm{N} 1$ to $\mathrm{N} 3$. A similar irrigation $\times \mathrm{N}$ interaction was also observed in terms of $\mathrm{N}$ uptake, In $\mathrm{N} 1$ treatments, the order of $\mathrm{N}$ uptake amount was -35 to $-20 \mathrm{kPa}>-50$ to $-5 \mathrm{kPa}>-20$ to $-5 \mathrm{kPa}>-50$ to $-35 \mathrm{kPa}$. While in N2 and N3, it was -35 to $-20 \mathrm{kPa}>-20$ to $-5 \mathrm{kPa}>-50$ to $-5 \mathrm{kPa}>-50$ to $-35 \mathrm{kPa}$. The impact of experimental year on the $\mathrm{N}$ accumulation was also significant $(2016<2017)$. In -50 to $-35 \mathrm{kPa}$ and -35 to $-20 \mathrm{kPa}$, comparing with $\mathrm{N} 2$, N3 improved the plant $\mathrm{N}$ accumulation, but had no beneficial effect on tomato yield, suggesting a luxury $\mathrm{N}$ consumption happened in $\mathrm{N} 3$ in these conditions.

Table 6. Nitrogen uptake under different $\mathrm{N} \times$ irrigation combinations in 2016 and $2017\left(\mathrm{~kg} \mathrm{ha}^{-1}\right)$

\begin{tabular}{|c|c|c|c|c|c|c|c|c|}
\hline \multirow{2}{*}{ Treatment } & \multicolumn{4}{|c|}{2016} & \multicolumn{4}{|c|}{$2017^{\mathrm{NS}}$} \\
\hline & N1 & N2 & N3 & Average & N1 & $\mathrm{N} 2$ & N3 & Average \\
\hline-50 to $-35 \mathrm{kPa}$ & $143.6 \mathrm{i}$ & $227.0 \mathrm{fg}$ & $248.3 \mathrm{ef}$ & $206.3 \mathrm{C}$ & $131.5 \mathrm{~h}$ & $219.0 \mathrm{f}$ & $242.3 \mathrm{df}$ & $197.6 \mathrm{C}$ \\
\hline-35 to $-20 \mathrm{kPa}$ & $252.3 \mathrm{e}$ & $369.1 \mathrm{a}$ & $384.5 \mathrm{a}$ & $335.3 \mathrm{~A}$ & $269.2 \mathrm{c}$ & $372.6 \mathrm{a}$ & $382.5 \mathrm{a}$ & $341.4 \mathrm{~A}$ \\
\hline-20 to- $5 \mathrm{kPa}$ & $185.4 \mathrm{~h}$ & $308.8 \mathrm{bc}$ & $312.9 \mathrm{~b}$ & $269.0 \mathrm{~B}$ & $190.5 \mathrm{~g}$ & $311.9 \mathrm{~b}$ & $305.6 \mathrm{~b}$ & $269.3 \mathrm{~B}$ \\
\hline-50 to- $5 \mathrm{kPa}$ & $213.6 \mathrm{~g}$ & $263.0 \mathrm{de}$ & $284.5 \mathrm{~cd}$ & $253.7 \mathrm{~B}$ & $224.6 \mathrm{f}$ & $262.2 \mathrm{~cd}$ & $278.1 \mathrm{c}$ & $255.0 \mathrm{~B}$ \\
\hline Average & 198.7 B & $292.0 \mathrm{~A}$ & $307.6 \mathrm{~A}$ & 266.1 & $204.0 \mathrm{~B}$ & $291.4 \mathrm{~A}$ & $302.1 \mathrm{~A}$ & 265.8 \\
\hline
\end{tabular}

\subsection{N Leaching}

The response of $\mathrm{N}$ leaching to different $\mathrm{N}$ and irrigation combinations was specific. As shown in Table 7, the leached $\mathrm{N}$ remarkabely increased with the increase of the amount of $\mathrm{N}$ fertilizer and irrigation water used (N3 $>$ $\mathrm{N} 2>\mathrm{N} 1,-20$ to $-5 \mathrm{kPa}>-50$ to $-5 \mathrm{kPa}>-35$ to $-20 \mathrm{kPa}>-50$ to $-35 \mathrm{kPa}$. There was no significant difference of $\mathrm{N}$ leaching data between 2016 and 2017. The $\mathrm{N}$ leaching seasonal evolution of combination N2 -50 to $-5 \mathrm{kPa}$ and $\mathrm{N} 2-35$ to $-20 \mathrm{kPa}$ in 2016 was list in Figure 4. Basically, the $\mathrm{N}$ leaching amount revealed a downtrend during the crop season. Other combinations also showed similar tend (data not shown). The results also indicated that the large amount of irrigation water at the first two days after transplanting result in severe $\mathrm{N}$ leakage. 
Table 7. Nitrogen leaching under different $\mathrm{N} \times$ irrigation combinations in 2016 and $2017\left(\mathrm{~kg} \mathrm{ha}^{-1}\right)$

\begin{tabular}{|c|c|c|c|c|c|c|c|c|}
\hline \multirow{2}{*}{ Treatment } & \multicolumn{4}{|c|}{2016} & \multicolumn{4}{|c|}{$2017^{\mathrm{NS}}$} \\
\hline & N1 & N2 & N3 & Average & N1 & N2 & N3 & Average \\
\hline-50 to $-35 \mathrm{kPa}$ & $31.6 \mathrm{i}$ & $57.3 \mathrm{fg}$ & $78.6 \mathrm{~d}$ & $55.8 \mathrm{D}$ & $29.3 \mathrm{j}$ & $58.4 \mathrm{~g}$ & $81.5 \mathrm{de}$ & $56.4 \mathrm{C}$ \\
\hline-35 to $-20 \mathrm{kPa}$ & $43.2 \mathrm{~h}$ & $70.4 \mathrm{e}$ & $94.3 \mathrm{c}$ & $69.3 \mathrm{C}$ & $41.6 \mathrm{i}$ & $72.3 \mathrm{f}$ & $96.7 \mathrm{~b}$ & $70.2 \mathrm{~B}$ \\
\hline-20 to $-5 \mathrm{kPa}$ & $59.4 \mathrm{f}$ & $89.2 \mathrm{c}$ & $121.7 \mathrm{a}$ & $90.1 \mathrm{~A}$ & $55.3 \mathrm{~g}$ & $88.6 \mathrm{c}$ & $119.3 \mathrm{a}$ & $87.7 \mathrm{~A}$ \\
\hline-50 to $-5 \mathrm{kPa}$ & $51.3 \mathrm{~g}$ & $79.6 \mathrm{~d}$ & $103.7 \mathrm{~b}$ & $78.2 \mathrm{~B}$ & $48.2 \mathrm{~h}$ & 76.4 ef & $100.2 \mathrm{~b}$ & $74.9 \mathrm{~B}$ \\
\hline Average & $46.4 \mathrm{C}$ & $74.1 \mathrm{~B}$ & $99.6 \mathrm{~A}$ & 73.4 & $43.6 \mathrm{C}$ & $73.9 \mathrm{~B}$ & $99.4 \mathrm{~A}$ & 72.3 \\
\hline
\end{tabular}

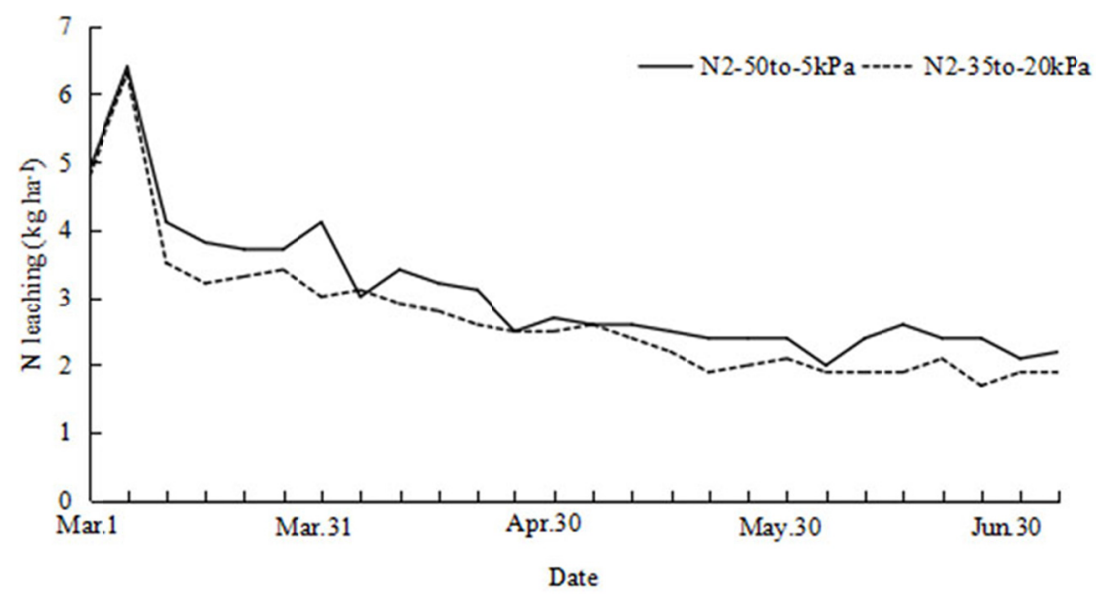

Figure 4. The $\mathrm{N}$ leaching seasonal evolution of combination N2 -50 to $-5 \mathrm{kPa}$ and N2-35 kPa to $-20 \mathrm{kPa}$ in 2016

\subsection{WUE of Different Treatments}

Basically, in three N treatments, the WUE data followed the pattern N3 $>\mathrm{N} 2>\mathrm{N} 1$. However, in -50 to $-35 \mathrm{kPa}$ and -35 to $-20 \mathrm{kPa}$ treatments, there was no significant difference of WUE between N2 and N3. The WUE difference between $\mathrm{N} 2$ and $\mathrm{N} 3$ was mostly found in -20 to $-5 \mathrm{kPa}$ and -50 to $-5 \mathrm{kPa}$ treatments. Among 4 irrigation treatments, the order of WUE was -35 to $-20 \mathrm{kPa}>-50 \mathrm{kPa}$ to $-35 \mathrm{kPa}>-50 \mathrm{kPa}$ to $-5 \mathrm{kPa}>-20 \mathrm{kPa}$ to $-5 \mathrm{kPa}$. In addition, the WUE of 2016 was significantly higher than that of 2017 , mostly due to the lower irrigation volume of water applied in 2016 than in 2017.

Table 8. Water use efficiency (WUE) under different $\mathrm{N} \times$ irrigation combinations in 2016 and $2017\left(\mathrm{~kg} \mathrm{~m}^{-3}\right)$

\begin{tabular}{|c|c|c|c|c|c|c|c|c|}
\hline \multirow{2}{*}{ Treatment } & \multicolumn{4}{|c|}{2016} & \multicolumn{4}{|c|}{$2017^{*}$} \\
\hline & N1 & $\mathrm{N} 2$ & N3 & Average & N1 & N2 & N3 & Average \\
\hline-50 to $-35 \mathrm{kPa}$ & $32.5 \mathrm{fg}$ & $42.4 \mathrm{bc}$ & $43.5 \mathrm{~b}$ & $39.5 \mathrm{~B}$ & $26.1 \mathrm{~g}$ & $36.3 \mathrm{~cd}$ & $37.6 \mathrm{bc}$ & $33.3 \mathrm{AB}$ \\
\hline-35 to $-20 \mathrm{kPa}$ & $36.7 \mathrm{e}$ & $47.3 \mathrm{a}$ & $46.5 \mathrm{a}$ & $43.5 \mathrm{~A}$ & $31.6 \mathrm{e}$ & $40.8 \mathrm{a}$ & $39.2 \mathrm{ab}$ & $37.2 \mathrm{~A}$ \\
\hline-20 to $-5 \mathrm{kPa}$ & $24.7 \mathrm{~h}$ & $34.3 \mathrm{f}$ & $38.8 \mathrm{~d}$ & $32.6 \mathrm{C}$ & $21.4 \mathrm{~h}$ & $29.7 \mathrm{f}$ & $31.8 \mathrm{e}$ & $27.6 \mathrm{C}$ \\
\hline-50 to $-5 \mathrm{kPa}$ & $32.2 \mathrm{~g}$ & $36.8 \mathrm{de}$ & $41.3 \mathrm{c}$ & $36.8 \mathrm{~B}$ & $27.6 \mathrm{~g}$ & $30.0 \mathrm{ef}$ & $34.6 \mathrm{~d}$ & $30.7 \mathrm{BC}$ \\
\hline Average & $31.5 \mathrm{~B}$ & $40.2 \mathrm{~A}$ & $42.5 \mathrm{~A}$ & 38.1 & $26.7 \mathrm{~B}$ & $34.2 \mathrm{~A}$ & $35.8 \mathrm{~A}$ & 32.3 \\
\hline
\end{tabular}

Note. * indicate the significantly difference between 2016 and 2017 at the 0.05 level. The same definitions apply to Table 9.

\subsection{NUE of Different Different $N \times$ Irrigation Combinations}

As shown in Table 9, the NUE increased significantly with the decreased $\mathrm{N}$ fertilizer rate in both years. Among 4 irrigation programs, the optimal NUE was observed in $-35 \mathrm{kPa}$ to $-20 \mathrm{kPa}$ and the lowest NUE was in $-50 \mathrm{kPa}$ to $-35 \mathrm{kPa}$, indicating water deficiency retarded $\mathrm{N}$ uptake in this occasion. In N1 treatment, the NUE of $-50 \mathrm{kPa}$ to $-5 \mathrm{kPa}$ was higher than that of $-20 \mathrm{kPa}$ to $-5 \mathrm{kPa}$, while in $\mathrm{N} 2$ and $\mathrm{N} 3$, the NUE of $-50 \mathrm{kPa}$ to $-5 \mathrm{kPa}$ was lower than that of $-20 \mathrm{kPa}$ to $-5 \mathrm{kPa}$. The NUE of 2017 was significantly higher than that of 2016 , mostly due to the less $\mathrm{N}$ chemical fertilizer applied in 2017 than in 2016. 
Table 9. Nitrogen use efficiency (NUE) under different $\mathrm{N} \times$ irrigation combinations in 2016 and 2017. $\left(\mathrm{kg} \mathrm{kg}^{-1}\right)$

\begin{tabular}{|c|c|c|c|c|c|c|c|c|}
\hline \multirow{2}{*}{ Treatment } & \multicolumn{4}{|c|}{$2016^{*}$} & \multicolumn{4}{|c|}{2017} \\
\hline & N1 & $\mathrm{N} 2$ & N3 & Average & N1 & $\mathrm{N} 2$ & N3 & Average \\
\hline-50 to $-35 \mathrm{kPa}$ & $358.3 \mathrm{e}$ & $311.6 \mathrm{fg}$ & $239.8 \mathrm{~h}$ & $303.2 \mathrm{~B}$ & $356.0 \mathrm{f}$ & $329.6 \mathrm{~g}$ & $256.4 \mathrm{i}$ & $314.0 \mathrm{~B}$ \\
\hline-35 to $-20 \mathrm{kPa}$ & $503.6 \mathrm{a}$ & $432.6 \mathrm{c}$ & $319.4 \mathrm{f}$ & $418.5 \mathrm{~A}$ & $541.5 \mathrm{a}$ & $466.9 \mathrm{c}$ & $336.4 \mathrm{~g}$ & $448.3 \mathrm{~A}$ \\
\hline-20 to $-5 \mathrm{kPa}$ & $419.0 \mathrm{c}$ & $388.2 \mathrm{~d}$ & $329.0 \mathrm{f}$ & $378.7 \mathrm{~A}$ & $444.1 \mathrm{~d}$ & $411.2 \mathrm{e}$ & $330.3 \mathrm{~g}$ & $395.2 \mathrm{~A}$ \\
\hline-50 to $-5 \mathrm{kPa}$ & $458.9 \mathrm{~b}$ & $349.5 \mathrm{e}$ & $294.9 \mathrm{~g}$ & $367.8 \mathrm{~A}$ & $491.1 \mathrm{~b}$ & $355.5 \mathrm{f}$ & $307.9 \mathrm{~h}$ & $384.8 \mathrm{~A}$ \\
\hline Average & $435.0 \mathrm{~A}$ & $370.5 \mathrm{~B}$ & $295.8 \mathrm{C}$ & 367.1 & $458.2 \mathrm{~A}$ & $390.8 \mathrm{~B}$ & $307.8 \mathrm{C}$ & 385.6 \\
\hline
\end{tabular}

\section{Discussion}

The study on sensor-based irrigation management has been conducted of many crops, including cotton, potato, onion, tomato and so on. The optional irrigation threshold of different crops always ranged from about $-20 \mathrm{kPa}$ to -40 kPa (Kang \& Wan, 2005; Kang, Wang, Liu, \& Yuan, 2004; Meeks et al., 2017; Shock, Feibert, \& Saunders, 2000). In this study, the best irrigation threshold is $-35 \mathrm{kPa}$, which was similar to that of other crops. Montesano et al. (2015) reported that $-30 \mathrm{hPa}$ to $-90 \mathrm{hPa}$ of substrate matric potential was suitable for soilless tomato production, indicating a large difference of hydrodynamics between soilless and soil production systems. Higher soil moisture has no impact or even negative impact on NUE, N uptake, dry matter and yield. The extra water may cause more $\mathrm{N}$ loss or oxygen deficit in the root zone, which lead to a reduced yield (Fiebig \& Dodd, 2016). In addition, high soil potential always has a negative effect on tomato fruit quality (Wang, Kang, Du, Li, \& Qiu, 2011; Wang \& Xing, 2017). To deal with the water shortage or improve the WUE in arid or semi-arid regions, several researches have tried lower irrigation threshold during crop growth. Wang, Kang, and Wan (2007) set 5 irrigation treatments (irrigation thresholds from $-10 \mathrm{kPa}$ to $-50 \mathrm{kPa}$ ) and found the soil matric potential did not affect the tomato yield significantly. Meeks et al. (2017) applied 4 irrigation thresholds (from $-20 \mathrm{kPa}$ to -100 $\mathrm{kPa}$ ) prior to cotton flowering and suggested that $-100 \mathrm{kPa}$ irrigation threshold can be applied to reduce irrigation times without yield loss. However, in this study, low soil moisture (-50 kPa irrigation threshold) significantly reduced the tomato yield, dry matter accumulation and $\mathrm{N}$ uptake. The surface fertigation system and high ground water table may result in a shallow root distribution (mostly in the $20 \mathrm{~cm}$ soil, field observation, data not shown), which leaded to a high sensitivity to water stress of tomato plants.

In this study, we fail to calculate the ETc (crop evapotranspiration) of tomato plants with the equation of water balance $\mathrm{ET}(\mathrm{mm})=(\mathrm{Pi}+\mathrm{I}+\mathrm{C})-(\mathrm{R}+\mathrm{D})+\Delta \mathrm{SWC}$ (in this equation, Pi means precipitation, I means irrigation, $\mathrm{C}$ mans the upward flux into the root zone, $\mathrm{R}$ means surface runoff, $\mathrm{D}$ means downward drainage out of the root zone and $\triangle \mathrm{SWC}$ means the change in soil water content between planting and harvesting), since we could not obtain the exact data of $\mathrm{C}$ and $\mathrm{D}$ in a soil with high groundwater table. Thus, we estimated the plant ETc with the equation $\mathrm{ETc}=\mathrm{ET}_{0} \times \mathrm{Kc}$, where $\mathrm{ET}_{0}$ (reference crop evapotranspiration) was estimated using the CROPWAT Software version 8.0 (Smith, 1992) with weather data detected from the experimental greenhouses, and Kc means the crop coefficient. The Kc durations and values were according to our records during plant growth and the data from Sun et al. (2013), similar tomato type and growth habit of this study). The estimated ETc of 2016 and 2017 was $353 \mathrm{~mm}$ and $406 \mathrm{~mm}$ respectively, which was far more than the optimal irrigation water amount ( $258 \mathrm{~mm}$ in 2016 and $310 \mathrm{~mm}$ in 2017) in this study. These results suggested that high groundwater table had a significant contribution on the evapotranspiration of tomato plants, and a sensor-based irrigation program might be more accurate than the simulated ETc methods to evaluate the water need in this occasion. In addition, the -35 to $-20 \mathrm{kPa}$ treatment consumed similar irrigation water as -50 to $-5 \mathrm{kPa}$ treatment but obtain significant higher yield, dry matter and $\mathrm{N}$ uptake than those of -50 to $-5 \mathrm{kPa}$ treatment, suggesting that frequent irrigation is critical to reduce $\mathrm{N}$ leaching and improve WUE or NUE in this condition.

The data of this research revealed that the three forth of the recommended $\mathrm{N}$ rate was enough to obtain the optimal tomato yield and higher $\mathrm{N}$ dosage would cause luxury $\mathrm{N}$ consumption and serious $\mathrm{N}$ leaching. The parameters used to estimate the recommended $\mathrm{N}$ dosage in this experiment were used from the conventional fertilization practice in the local region directly, suggesting that the NUE of the sensor-based fertigation methods was remarkably higher than that of the conventional practice and the parameters about NUE should be reappraised for the new fertigation methods. Furthermore, our results indicated that the $\mathrm{N}$ leakage decreased and the groundwater level increased along the growth season and there was a negative correction between the $\mathrm{N}$ leakage and the groundwater level (Figures 3 and 4). Morari, Lugato, Polese, Berti, and Giardini (2012) reported that soil $\mathrm{N}$ and water downward movement was retarded and $\mathrm{N}$ leakage was reduced by the high water table. Our results suggested that the high groundwater level may play a similar role in this study. In a word, the soil nutrient 
and water dynamics of the sensor-based fertigation system still need to be further researched to optimize the plastic tunnel vegetable management in this shallow groundwater region.

\section{Conclusions}

Surface fertigation-cultured tomato plants were sensitive to water supply in shallow water table regions. The results showed that the -35 to $-20 \mathrm{kPa}$ treatment was optimum to gain the highest tomato yield, NUE and WUE. In this treatment, the total irrigation water amount was far less than the value of estimated ETc, suggesting high groundwater level had a significant contribution on the tomato plant evapotranspiration. Comparing with conventional fertilization practice, the new sensor-based fertigation system improved the nutrient use efficiency significantly. The result indicated that three forth of the recommended $\mathrm{N}$ rate was enough for tomato growth and high $\mathrm{N}$ dosage cause luxury $\mathrm{N}$ consumption and severe $\mathrm{N}$ leakage. Finally, the recommended sensor-based fertigation strategy in these conditions was the combination of -35 to $-20 \mathrm{kPa}$ irrigation and three forth of the recommended $\mathrm{N}$ treatment, in which the highest tomato yield (121.9 tons ha $\left.{ }^{-1}\right)$, WUE and NUE were achieved (data from the experiment of 2016).

\section{Acknowledgements}

This work was supported by the National Key Research and Development Program (2018YFD1000800), the Jiangsu Agricultural Science and Technology Innovation Fund (CX(19)3034) and Key R\&D Program (Modern Agriculture) of Jiangsu Province (BE2018359).

\section{References}

Bremner, J. M., \& Mulvaney, C. S. (1982). Nitrogen: Total. In A. L. Page, R. H. Miller, \& D. R. Keeney (Eds.), Methods of Soil Analysis. Part 2. Agronomy Monograph 9 (pp. 595-623). Madison, WI: American Society of Agronomy, Soil Science Society of America.

Du, Y. D., Cao, H. X., Liu, S. Q., Gu, X. B., \& Cao, Y. X. (2017). Response of yield, quality, water and nitrogen use efficiency of tomato to different levels of water and nitrogen under drip irrigation in Northwestern China. Journal of Integrative Agriculture, 16(5), 1153-1161. https://doi.org/10.1016/S2095-3119(16) 61371-0

Fiebig, A., \& Dodd, I. C. (2016). Inhibition of tomato shoot growth by over-irrigation is linked to nitrogen deficiency and ethylene. Physiologia Plantarum, 156(1), 70-83. https://doi.org/10.1111/ppl.12343

Han, M., Zhao, C. Y., Šimùnek, J., \& Feng, G. (2015). Evaluating the impact of groundwater on cotton growth and root zone water balance using Hydrus-1D coupled with a crop growth model. Agricultural Water Management, 160, 64-75. https://doi.org/10.1016/j.agwat.2015.06.028

He, F. F., Chen, Q., Jiang, R. F., Chen, X. P., \& Zhang, F. S. (2007). Yield and nitrogen balance of greenhouse tomato (Lycopersicum esculentum Mill.) with conventional and site-specific nitrogen management in Northern China. Nutrient Cycling in Agroecosystems, 77(1), 1-14. https://doi.org/10.1007/s10705-0066275-7

Hou, M. M., Jin, Q., Lu, X. Y., Li, J. Y., Zhong, H. Z., \& Gao, Y. (2017). Growth, water use, and nitrate- 15 N uptake of greenhouse tomato as influenced by different irrigation patterns, $15 \mathrm{~N}$ labeled depths, and transplant times. Frontiers Plant Science, 8, 666. https://doi.org/10.3389/fpls.2017.00666

Kang, Y. H., \& Wan, S. Q. (2005). Effect of soil water potential on radish (Raphanus sativus L.) growth and water use under drip irrigation. Scientia Horticulturae, 106(3), 275-292. https://doi.org/10.1016/j.scienta. 2005.03.012

Kang, Y. H., Wang, F. X., Liu, H. J., \& Yuan, B. Z. (2004). Potato evapotranspiration and yield under different drip irrigation regimes. Irrigation Science, 23(3), 133-143. https://doi.org/10.1007/s00271-004-0101-2

Li, X. L., Liu, F. L., Li, G. T., Lin, Q. M., \& Jensen, C. R. (2010). Soil microbial response, water and nitrogen use by tomato under different irrigation regimes. Agricultural Water Management, 98(3), 414-418. https://doi.org/10.1016/j.agwat.2010.10.008

Liu, Y., Pereira, L. S., \& Fernando, R.M. (2006). Fluxes through the bottom boundary of the root zone in silty soils: Parametric approaches to estimate groundwater contribution and percolation. Agricultural Water Management, 84(1-2), 27-40. https://doi.org/10.1016/j.agwat.2006.01.018

Lu, R. K. (1999). Analysis Method of Soil Agrichemistry. Beijing, China Agricultural Technology Publishing House. 
Meeks, C. D., Snider, J. L., Porter, W. M., Vellidis, G., Hawkins, G., \& Rowland, D. (2017). Assessing the utility of primed acclimation for improving water savings in cotton using a sensor-based irrigation scheduling system. Crop Science, 57(4), 2117-2129. https://doi.org/10.2135/cropsci2016.10.0907

Ministry of Agriculture of the P.R. China. (2014). China agriculture statistical report 2013. Beijing, China Agriculture Press.

Montesano, F. F., Serio, F., Mininni, C., Signore, A., Parente, A., \& Santamaria, P. (2015). Tensiometer-based irrigation management of subirrigated soilless tomato: effects of substrate matric potential control on crop performance. Frontiers Plant Science, 6, 1150. https://doi.org/10.3389/fpls.2015.01150

Morari, F., Lugato, E., Polese, R., Berti, A., \& Giardini, L. (2012). Nitrate concentrations in groundwater under contrasting agricultural management practices in the low plains of Italy. Agriculture, Ecosystem Environment, 147, 47-56. https://doi.org/10.1016/j.agee.2011.03.001

Ramos, T. B., Simionesei, L., Jauch, E., Almeida, C., \& Neves, R. (2017). Modelling soil water and maize growth dynamics influenced by shallow groundwater conditions in the Sorraia Valley region, Portugal. Agricultural Water Management, 185, 27-42. https://doi.org/10.1016/j.agwat.2017.02.007

Shock, C. C., Feibert, E. B. G., \& Saunders, L. D. (2000). Irrigation criteria for drip-irrigated onions. HortScience, 35(1), 63-66. https://doi.org/10.21273/HORTSCI.35.1.63

Smith, M. (1992). CROPWAT: A computer program for irrigation planning and management. Paper No. 46 Presented at the FAO Irrigation and Drainage, Rome, Italy. Retrieved from http://agris.fao.org/agris-search/ search.do?recordID $=$ SO2005100017

Sun, Y., Hu, K. L., Fan, Z. B., Wei, Y. P., Lin, S., \& Wang, J. G. (2013). Simulating the fate of nitrogen and optimizing water and nitrogen management of greenhouse tomato in North China using the EU-Rotate_N model. Agricultural Water Management, 128, 72-84. https://doi.org/10.1016/j.agwat.2013.06.016

Wang, D., Kang, Y. H., \& Wan, S. Q. (2007). Effect of soil matric potential on tomato yield and water use under drip irrigation condition. Agricultural Water Management, 87(2), 180-186. https://doi.org/10.1016/ j.agwat.2006.06.021

Wang, F., Kang, S. Z., Du, T. S., Li, F. S., \& Qiu, R. J. (2011). Determination of comprehensive quality index for tomato and its response to different irrigation treatments. Agricultural Water Management, 98(8), 1228-1238. https://doi.org/10.1016/j.agwat.2011.03.004

Wang, X. K., \& Xing, Y. Y. (2016). Evaluation of the effect of irrigation and fertilization by drip fertigation on tomato yield and water use efficiency in greenhouse. International Journal Agronomy, 2016, Article ID 3961903. https://doi.org/10.1155/2016/3961903

Wang, X. K., \& Xing, Y. Y. (2017). Evaluation of the effects of irrigation and fertilization on tomato fruit yield and quality: A principal component analysis. Scientific Reports, 7, 350. https://doi.org/10.1038/s41598017-00373-8

Wu, Y., Liu, T. X., Paredes, P., Duan, L. M., \& Pereira, L. S. (2015). Water use by a groundwater dependent maize in a semi-arid region of Inner Mongolia: Evapotranspiration partitioning and capillary rise. Agricultural Water Management, 152, 222-232. https://doi.org/10.1016/j.agwat.2015.01.016

Zotarelli, L., Scholberg, J. M., Dukes, M. D., Muñozcarpena, R., \& Icerman, J. (2009). Tomato yield, biomass accumulation, root distribution and irrigation water use efficiency on a sandy soil, as affected by nitrogen rate and irrigation scheduling. Agricultural Water Management, 96(1), 23-34. https://doi.org/10.1016/ j.agwat.2008.06.007

\section{Copyrights}

Copyright for this article is retained by the author(s), with first publication rights granted to the journal.

This is an open-access article distributed under the terms and conditions of the Creative Commons Attribution license (http://creativecommons.org/licenses/by/4.0/). 